\title{
The Effect of Transformational Leadership and Organizational Commitments to Organizational Citizenship Behavior for The Environment (OCBE) with Job Satisfaction as Intervening Variables
}

\author{
Faisal Luthfi ${ }^{1}$, Lenny Christina Nawangsari ${ }^{2}$ \\ \{luthfi.faisal@gmail.comd ${ }^{1}$, lenny.christina@mercubuana.ac.id ${ }^{2}$ \}
}

Mercu Buana University, Indonesia ${ }^{12}$

\begin{abstract}
Nowadays employees demonstrate voluntary efforts to help their organizations become greener or better known as Organizational Citizenship Behavior for the Environment (OCBE). The purpose of this study is the way to understand and explain the effect of Transformational Leadership and Organizational Commitment to Organizational Citizenship Behavior for the Environment (OCBE) employees of Suku Dinas Cipta Karya, Tata Ruang dan Pertanahan Kota Administrasi Jakarta Utara with Job Satisfaction as an intervening variable. The research method uses quantitative approach, which takes 60 respondents by questionnaire. The questioner uses Likert Scale with 5 levels of answers. The data collection the quiches by questionnaires to employees of Suku Dinas Cipta Karya, Tata Ruang dan Pertanahan Kota Administrasi Jakarta Utara. The data analysis is using the SEM (Structural Equation Modeling) method by the Software SmartPLS (Partial Least Square) version 3.2.9. The results of the study are as follows: (1) Transformational Leadership has a positive and significant effect on Job Satisfaction, (2) Organizational Commitment has a positive and significant effect on Job Satisfaction, (3) Job Satisfaction has a positive and significant effect on OCBE, (4) Transformational Leadership has a positive and significant effect on OCBE, (5) Organizational Commitment has no effect and not significant on OCBE, (6) Transformational Leadership has a positive and significant effect on OCBE through Job Satisfaction, and (7) Organizational Commitment has a positive and significant effect on OCBE through Job Satisfaction.
\end{abstract}

Keywords: Transformational Leadership, Organizational Commitment, OCBE, Job Satisfaction

\section{Introduction}

Humans and the environment are very dependent on one another. Human life is greatly influenced by environmental factors. Vice versa, environmental factors can be influenced by human activities and behavior. The position of humans as subjects in the utilization of natural resources, sometimes makes people forget themselves because they are driven by the desire to meet their needs. The development process is often carried out only to pursue economic growth, without considering aspects of environmental sustainability that cause environmental damage. The current development and problem situation is the occurrence of environmental damage that has turned into a complex social problem. Companies or business 
people not only aim to survive in the harshness of business competition and generate profits from their business fields, but are also required to make a positive contribution to their social environment. Human resource management has to be able to fulfill all organization needs, moreover, Green Human Resource Management become a key issue in an organization and become a strategy to improve Competition in the business World [1].

In everyday life, a person is faced with a variety of behavioral choices, both those that damage the environment and those that benefit the environment. Now many actions have begun to emerge and focus on voluntary forms of collaboration where employees demonstrate voluntary efforts to help their organizations become greener or better known as Organizational Citizenship Behavior for the Environment (OCBE). Organizational Citizenship Behavior for the Environment (OCBE) is defined as voluntary actions taken by employees in organizations that lead to environmental improvement without any request or appreciation from the organization [2].

The problem discussed in this study is how the application of OCBE in government institutions because based on a study by PT Energy Management Indonesia (EMI), it turns out that government buildings are more wasteful in the use of electricity compared to the household sector, private office buildings, industry, markets, and shops. The average energy waste in households is $10 \%$, in private office buildings $20 \%$, industry $25 \%$, shops and markets $25 \%$, while in government offices it can reach $25-30 \%$. From the results of the presurvey of the employees of Suku Dinas Cipta Karya, Tata Ruang dan Pertanahan Kota Administrasi Jakarta Utara, related to OCBE's behavior in their work environment showed that only $58 \%$ of employees had implemented OCBE well, while the other $48 \%$ had not implemented OCBE properly. This means that the application of OCBE in this government institutions is not optimal.

There are at least 8 variables that influence OCBE, namely: job satisfaction, organizational commitment, transformational leadership, green training, environmental awareness, employee green behavior, organizational culture and psychological ownership. From these variables, a pre-survey was conducted to obtain 3 variables which according to respondents most influential on OCBE in the research object organization, and the results obtained were Transformational Leadership, Organizational Commitment and Job Satisfaction. After getting the pre-survey results of the 3 factors that most influence OCBE, a further pre-survey is conducted to find out how much influence the variables that support the OCBE implementation. From the results of the pre-survey follow-up, it can be seen that there is still not a maximum of factors that affect employees behaving OCBE.

For the Transformational Leadership factor of 3 (three) statements, it was found that the average respondent stated that the agreed was $56 \%$, meaning that there was still a gap of $44 \%$ which needed to be improved in terms of Transformational Leadership that supported OCBE employee behavior. Organizational Commitment factor from 3 (three) statements obtained an average of $49 \%$ who agreed, this result also illustrates the lack of optimal organizational culture that supports OCBE employee behavior. As for the Job Satisfaction factor of 3 (three) statements obtained an average of $48 \%$ who agreed, this is the lowest average value of the 3 factors affecting the OCBE behavior of employees tested.

Based on the description described above, the author is interested in conducting a study entitled "The Effect of Transformational Leadership and Organizational Commitment to Organizational Citizenship Behavior for the Environment (OCBE) with Job Satisfaction as Intervening Variables, Case Study Employees of Suku Dinas Cipta Karya, Tata Ruang dan Pertanahan Kota Administrasi Jakarta Utara". 
The hypotheses of this study are as follows:

H1: Transformational Leadership has a positive and significant effect on job satisfaction

$\mathrm{H} 2$ : Organizational commitment has a positive and significant effect on job satisfaction

H3: Job satisfaction has a positive and significant effect on OCBE

H4: Transformational Leadership has a positive and significant effect on OCBE

H5: Organizational commitment has a positive and significant effect on OCBE

H6: Transformational Leadership has a positive and significant effect on OCBE through Job Satisfaction

H7: Organizational Commitment has a positive and significant effect on OCBE through Job Satisfaction

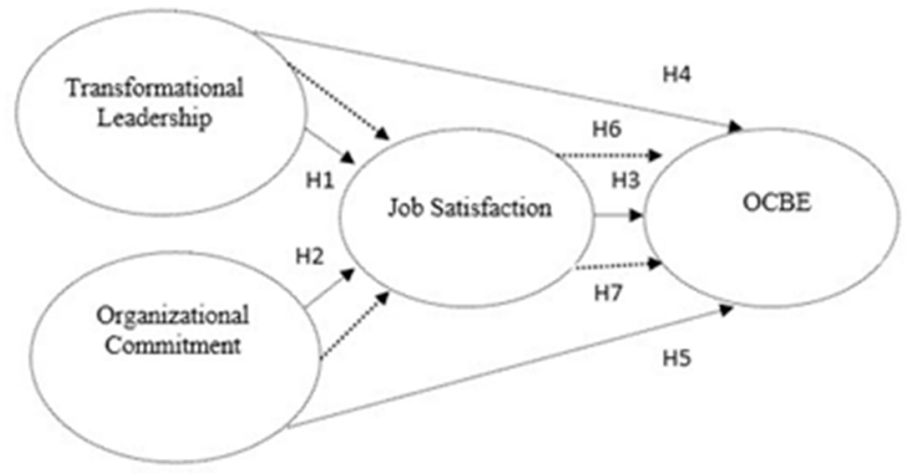

Fig 1. Theorical Framework

\subsection{Literature Review}

\subsubsection{Transformational Leadership}

Transformational leadership is the attitude of leaders who can change and motivate followers by making followers more aware of the importance of task results, persuading followers to prioritize organizational interests rather than personal interests, and activating needs the higher followers [3]. Transformational leadership is a leader who can stimulate and inspire his subordinates to achieve his vision and teach him to strive for that vision [4].

\subsubsection{Organizational Commitment}

Organizational commitment is a situation where an employee sides with a particular organization along with its goals and there is a desire to maintain membership in the organization [5], whereas Luthan argues that organizational commitment is a strong desire to remain as a member of a particular organization, a desire to strive in accordance with organizational desires and certain beliefs as well as acceptance of organizational values and goals [6].

\subsubsection{Job Satisfaction}

Job satisfaction as positive feelings about work, which result from evaluating the individual characteristics of their employees. Someone with a high level of job satisfaction produces positive feelings about his work, while people with a low level produce negative feelings [7]. Job satisfaction is the result of an employee's perception of how well the job in providing the thing that important [8]. 


\subsubsection{Organization Citizenship Behavior for the Environment (OCBE)}

OCBE defined as discretionary acts by employees within the organization not rewarded or required that are directed toward environmental improvement [9]. OCBE refers as a voluntary action taken by employees towards environmental improvement in the organization [10].

\section{Research Method}

This type of research is quantitative research. This research is accompanied by activities that include data collection in order to test hypotheses to answer questions concerning phenomena and their relationships with the subject matter of a study. This research was conducted with the object of employees Suku Dinas Cipta Karya, Tata Ruang dan Pertanahan Kota Administrasi Jakarta Utara in October 2019 until April 2020. The variables in this study are Transformational Leadership (X1) and Organizational Commitment (X2) as the independent variable, OCBE (Y2) as the dependent variable, and Job Satisfaction (Y1) as an intervening variable. The population and sample in this study were all employees of Suku Dinas Cipta Karya, Tata Ruang dan Pertanahan Kota Administrasi Jakarta Utara totaling 60 people.

The measurement of each variable, from the Transformational Leadership variables (X1) Bass and Avolio in Ahmad. et.al (2014) states that there are four dimensions of transformational leadership, those are: Idealized Influence, Individualized Consideration, Inspirational Motivation, Intellectual stimulation. Organizational commitment variables (X2) of the theory Meyer \& Allen have three dimensions, those are: affective commitment, continuance commitment, normative commitment. Job satisfaction variables (Y1) according to Smith et.al (1969) have five dimensions, those are: Work, Supervision, Wage, Promotion, Co-Workers. The organization citizenship behavior for the environment variable (Y2) from the Boiral and Paille theories has three dimensions, those are; eco-initiatives (dumping waste into place, shutting down electricity when not needed), eco-civic engagement (always up to date the information about the environment, positively contributing environmental action), eco-helping (spontaneously giving time to help coworkers, provides examples to coworkers to behave environmentally friendly).

This study used regression analysis (Partial Least Square)/PLS to test the seven hypotheses proposed in this study. Each hypothesis will be analyzed using SmartPLS version 3.2.9 software to test the relationship between variables. PLS is a predictive technique that can solve many independent variables, even if there is multicollinearity between these variables. The PLS method is a powerful analytical method because it does not assume the data must be of a certain scale measurement, the number of samples is small. The purpose of PLS is to help researchers to get the value of latent variables (hypothesis testing) for predictive purposes. 


\section{Results and Discussion}

\subsection{Result}

Respondents in this study were 60 employees of Suku Dinas Cipta Karya, Tata Ruang dan Pertanahan Kota Administrasi Jakarta Utara. The composition of respondents in this study was the most male sex of 40 people $(67 \%)$ compared with 20 women $(33 \%)$. Based on the latest education, the majority of respondents have a $\mathrm{S} 1$ education as much as 31 people $(52 \%), 15$ people $(25 \%)$ have a high school education, 6 people $(10 \%)$ have a D3 education, and 8 people $(13 \%)$ have a S2 education. If viewed from the working period, the majority have worked $10-15$ years $(35 \%)$, 5 people $(9 \%)$ less than 5 years, 17 people $(28 \%)$ have worked 5-10 years, and the remaining 17 people (28\%) have worked for more than 15 years. In terms of age, the majority of respondents are still in the productive period of 36-50 years as many as 39 people $(65 \%), 10$ people (17\%) aged 25-35 years, and the remaining 11 people $(18 \%)$ aged over 50 years

\subsubsection{Outer Model}

\subsubsection{Convergent Validity}

An indicator is considered to have a high level of validity if it has a loading factor value above 0.70 [11]
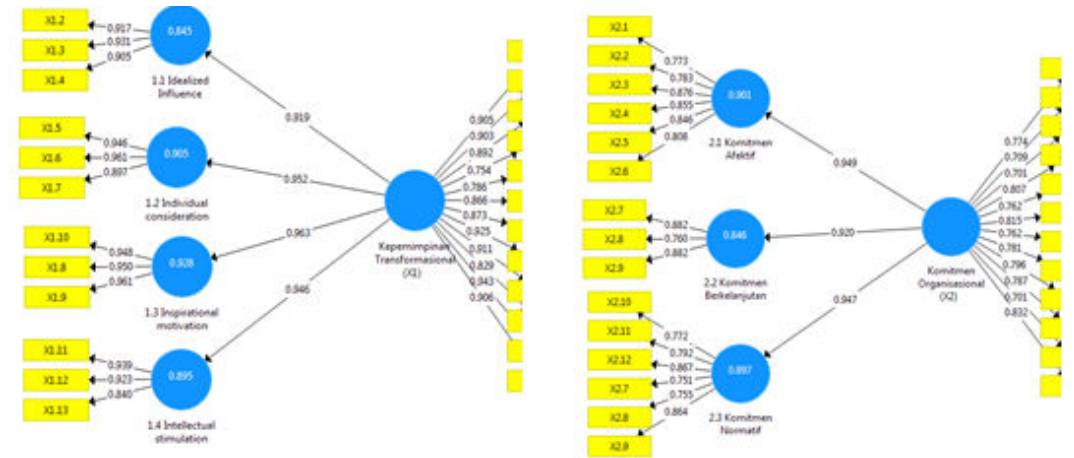

Fig 2. Loading Factor of Transformational Leadership and Organizational Commitment
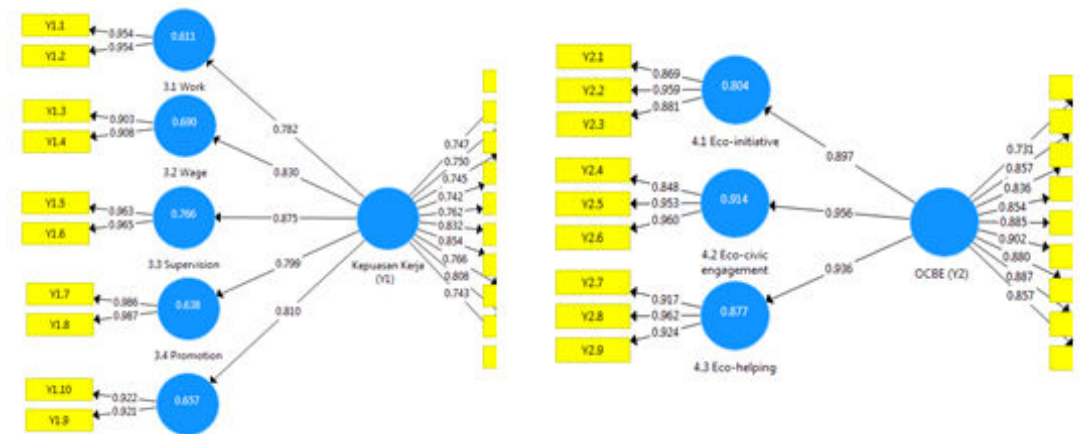

Fig 3. Loading Factor of Job Satisfaction and OCBE 
From Figure 2-3 there can be seen that the entire loading factor value of each indicator in the variable and its dimensions are above 0.7 . This proves that all variable indicators used in this study are valid or have fulfilled convergent validity.

\subsubsection{Discriminant Validity}

Table. 1 AVE (Average Variance Extraction)

\begin{tabular}{cc}
\hline Variable & $\begin{array}{c}\text { AVE } \\
\text { Value }\end{array}$ \\
\hline Transformational Leadership (X1) & 0.768 \\
\hline Organizational Commitment (X2) & 0.592 \\
\hline Job Satisfaction (Y1) & 0.600 \\
\hline OCBE (Y2) & 0.732 \\
\hline
\end{tabular}

AVE value is good if it has a value above 0.50 [11]. It can be seen from the table that the AVE Value for all research variables and research dimensions has a value above 0.5 so that the AVE value for discriminant validity testing has been fulfilled for further testing.

\subsubsection{Reliability Test}

Table 2 Composite Reliability and Cronbach's Alpha Value

\begin{tabular}{lccl}
\hline \multicolumn{1}{c}{ Variable } & $\begin{array}{c}\text { Composite } \\
\text { Reliability }\end{array}$ & $\begin{array}{c}\text { Cronbach's } \\
\text { Alpha }\end{array}$ & Remarks \\
\hline Transformational Leadership (X1) & 0.975 & 0.972 & Reliable \\
\hline Organizational Commitment (X2) & 0.946 & 0.937 & Reliable \\
\hline Job Satisfaction (Y1) & 0.937 & 0.926 & Reliable \\
\hline OCBE (Y2) & 0.961 & 0.954 & Reliable \\
\hline
\end{tabular}

Construct is reliable if the composite reliability value is above 0.7 and the Cronbach's value is above 0.6 [11]. From the above model, it can be concluded that the model meets the Composite Reliability and Cronbach's Alpha criteria so that the research model meets the Reliability criteria and is a reliable and reliable measuring tool.

\subsubsection{Inner model}

For structural model (inner model) or hypothesis test in this study based on the calculation of SmartPLS version 3.2.9 as table below:

Table 4 R Square Value $\left(R^{2}\right)$ of the Research Model

\begin{tabular}{lcc}
\hline \multicolumn{1}{c}{ Construct } & $\boldsymbol{R}$ Square & $\begin{array}{c}\boldsymbol{R} \text { Square } \\
\text { Adjusted }\end{array}$ \\
\hline Job Satisfaction (Y1) & 0.724 & 0.714 \\
\hline OCBE (Y2) & 0.668 & 0.650 \\
\hline
\end{tabular}


Based on the R-square Adjusted value can be explained that the Job Satisfaction variable (Y1) is equal to 0714 , this shows that $71.4 \%$ of the Job Satisfaction variable (Y1) can be influenced by the Transformational Leadership variable (X1), and Organizational Commitment (X2), while the remaining $28.6 \%$ is influenced by other variables outside the study. While the relationship between constructs based on the R-square Adjusted value can be explained that the OCBE variable (Y2) is equal to 0.650 , this shows that $65, \%$ OCBE variable (Y2) can be influenced by the Transformational Leadership variable (X1), Organizational Commitment (X2), and Job Satisfaction variable (Y1), while the remaining $35.0 \%$ is influenced by other variables outside the study.

\subsubsection{Goodness of Fit Index (GoF)}

The purpose of conducting Goodness of Fit Index (GoF) to validate the combined performance between the measuring model (outer model) and the structural model (inner model) obtained through the following calculations:

$\mathrm{GoF}=\sqrt{A V E x R^{2}}$

$\mathrm{GoF}=0.684$

The calculation result of Goodness of Fit Index (GoF) indicates a value of 0.684 . According to Ghazali (2016) [11], the value of GoF small $=0.1$, GoF medium $=0.25$ and big $\mathrm{GoF}=0.36$. Based on these results it can be concluded that the combined performance between the outer model and structural model (inner model) as a whole is good because the value of Goodness of Fit Index (GoF) is more than 0.36 (large scale GoF).

\subsubsection{Hypothesis Test}

Hypothesis testing between constructs is done by bootstrapping resampling method. Calculation of Hypothesis Testing using SmartPLS 3.2.9 can be seen from the Path Coefficient value, which is the t-statistic value of the relationship between variables in the study. T test statistics by using formulas or by using SmartPLS 3.2.9 can be seen from the comparison between $\mathrm{t}$ test values and values in $\mathrm{t}$ tables obtained from formulas

$$
\begin{aligned}
& \mathrm{DF}=\mathrm{n}-\mathrm{k} \\
& \mathrm{DF}=60-4=56
\end{aligned}
$$

In the statistics table, the $\mathrm{T}$ value of the table with a value of 56 is 2 with the equivalent significance $(\alpha)$ of 0.05 . The decision-making way is: if $P$-Values $>0,05$ or $t$ count $<t$ table, Ho accepted and Ha refused., but if P-Values $<0,05$ or $t$ count $>t$ table, Ho refused and Ha accepted. Hypothesis testing Results using software SmartPLS 3.2.9 can be seen in the following table: 
Table 5. Value of Path Coefficient, t-Statistics, and P-Values

\begin{tabular}{lllll}
\hline \multicolumn{1}{c}{$\begin{array}{c}\text { Relationship Between } \\
\text { Constructions }\end{array}$} & $\begin{array}{c}\text { Original } \\
\text { Sample } \\
(\mathbf{O})\end{array}$ & $\begin{array}{c}\text { T Statistics } \\
(\mid \mathbf{O} / \mathbf{S T D E V})\end{array}$ & P Values & $\begin{array}{c}\text { Hypothesis } \\
\text { Testing } \\
\text { Results }\end{array}$ \\
\hline Direct effect & & & & \\
\hline $\begin{array}{l}\text { Transformational Leadership - } \\
\text { > Job Satisfaction }\end{array}$ & 0.507 & 6.865 & 0.000 & Accepted \\
\hline $\begin{array}{l}\text { Transformational Leadership - } \\
\text { > OCBE }\end{array}$ & 0.529 & 5.159 & 0.000 & Accepted \\
\hline Job Satisfaction -> OCBE & 0.423 & 3.078 & 0.002 & Accepted \\
\hline $\begin{array}{l}\text { Organizational Commitment - } \\
\text { > Job Satisfaction }\end{array}$ & 0.496 & 5.636 & 0.000 & Accepted \\
\hline $\begin{array}{l}\text { Organizational Commitment - } \\
\text { > OCBE }\end{array}$ & -0.121 & 1.178 & 0.239 & Refused \\
\hline \begin{tabular}{l} 
Indirect effect \\
\hline $\begin{array}{l}\text { Transformational Leadership - } \\
\text { > Job Satisfaction -> OCBE }\end{array}$
\end{tabular} & 0.214 & 2.708 & 0.007 & Accepted \\
\hline $\begin{array}{l}\text { Organizational Commitment - } \\
\text { > Job Satisfaction -> OCBE }\end{array}$ & 0.210 & 2.628 & 0.009 & Accepted \\
\hline
\end{tabular}



Fig 5. Hypothesis Testing Using SmartPLS 3.2.

\subsection{Discussion}

\subsubsection{The Effect of Transformational Leadership on Job Satisfaction}

Based on the results of hypothesis testing, it shows that Transformational Leadership has a positive and significant effect on Job Satisfaction, meaning that one way to improve Job Satisfaction in an organization is through Transformational Leadership of the organization. The things that are most influential and must be in Transformational Leadership are the Inspirational motivation of the leader, so that employee job satisfaction will increase. The results of this study have results that are in line with the previous rigorous 
research by Dimitrios Belias, et. al (2014) [12], and Daniel Martins Abelha, et. al (2018) [13] which states that transformational leadership has a positive and significant effect on job satisfaction.

\subsubsection{The Effect of Transformational Leadership on OCBE}

Based on the results of hypothesis testing, it shows that Transformational Leadership has a positive and significant effect on OCBE. The results of this study have results that are in line with previous rigorous research by Lingyun Mi, et.al (2019) [14] which states that transformational leadership has a positive and significant effect on OCBE. The most influential factors of the Transformational Leadership variable on OCBE are the dimensions of Inspirational motivation with eco-civic engagement.

\subsubsection{The Effect of Job Satisfaction on OCBE}

Based on the results of hypothesis testing, it is proven that Job Satisfaction has a positive and significant effect on OCBE. This result is supported by previous research conducted by Eliana Sari, et.al (2019) [15] and A.M. Nur Huda Kalimullah \& Lenny Christina Nawangsari (2019) [16] which states that Job Satisfaction has a positive and significant effect on OCBE. The most influential factors of job satisfaction variables on $\mathrm{OCBE}$ are the promotion dimension with eco-initiative.

\subsubsection{The Effect of Organizational Commitment on Job Satisfaction}

Based on the results of hypothesis testing, it is evident that Organizational Commitment has a positive and significant effect on Job Satisfaction. This result is supported by previous research conducted by Atif Anis, et.al (2011) [17], and Brian Hartono, et.al (2013) [18] which states that Organizational Commitment has a positive and significant effect on Job Satisfaction. The things that most influence on Organizational Commitment are the dimensions of normative commitment with the dimension of work itself.

\subsubsection{The Effect of Organizational Commitment on OCBE}

Based on the results of hypothesis testing, it shows that Organizational Commitment has no effect and is not significant to OCBE. The results of this study are supported by previous research conducted by Pascal Paille, Olivier Boiral and Yang Chen, (2013) [2] which states that organizational commitment has no effect on OCBE. This can be seen from the low correlation between the dimensions of organizational commitment variables with OCBE so that in this study Organizational Commitment has no effect and is not significant on OCBE.

\subsubsection{The Effect of Transformational Leadership on OCBE through Job Satisfaction}

Based on the results of hypothesis testing, Transformational Leadership has a positive and significant effect on Employee OCBE through Job Satisfaction. In this study it was found that the results of the direct and indirect effect hypothesis test shows that the value of the influence of Transformational Leadership on OCBE is directly higher when compared to indirect through Job Satisfaction. Leadership which is a role model in green behavior, can influence, direct, support and always motivate employees to behave in an environmentally friendly manner. 


\subsubsection{The Effect of Organizational Commitment on OCBE through Job Satisfaction}

Based on the results of hypothesis testing, Organizational Commitment has a positive and significant effect on OCBE Employees through Job Satisfaction. In this study it was found that the results of the direct and indirect effect hypothesis test showed that Organizational Commitment had a positive and significant effect on OCBE indirectly through Job Satisfaction compared to if direct Organizational Commitment actually had no effect and no significant effect on OCBE. This means that the commitment of employees towards proenvironment activities will increase if the job satisfaction of these employees also increases

\section{Conclusion}

The conclusion of the study are as follows: Transformational Leadership has a positive and significant effect on Job Satisfaction, Organizational Commitment has a positive and significant effect on Job Satisfaction, Job Satisfaction has a positive and significant effect on OCBE, Transformational Leadership has a positive and significant effect on OCBE, Organizational Commitment has no effect and not significant on OCBE, Transformational Leadership has a positive and significant effect on OCBE through Job Satisfaction, and Organizational Commitment has a positive and significant effect on OCBE through Job Satisfaction.

\section{References}

[1] Nawangsari, L. C., \& Sutawidjaya, A. H. (2019, May). How the Green Human Resources Management (GHRM) Process Can Be Adopted for the Organization Business? In 1st International Conference on Economics, Business, Entrepreneurship, and Finance (ICEBEF 2018). Atlantis Press.

[2] Paille, Pascal., Boiral, O,. Chen, Yang. (2013). Linking environmental management practices and organizational citizenship behaviour for the environment: a social exchange perspective. The International Journal of Human Resource Management, Vol. 24, No. 18, pp 3552-3575

[3] Lomanjaya, J, dkk. (2014). Analisis Pengaruh Gaya Kepemimpinan Transformasional dan Transaksional Terhadap Kinerja Karyawan PT. ISS Indonesia Cabang Surabaya Di Rumah Sakit Katolik St. Vincentius A. Paulo. Jurnal Hospitality dan Manajemen Jasa. Vol. 2, No.1, pp 1-12

[4] McShane, Steven L dan Glinow, M.A Von. (2010). Organizational Behavior: Emerging Knowledge and Practice for the Real World. 5th Edition. McGraw Hill Companies, Inc. New York

[5] Robbins, S. \& Judge, T. A. (2011). Organizational Behaviour. 14th Global ed. McGraw-Hill. New Jersey

[6] Luthans, Fred. (2011). Organizational Behavior : An Evidence-Based Approach. New York: McGraw-Hill.

[7] Robins, J. \& Judge, T.A. (2013). Organizational Behaviour. 15th Global Edition. Pearson. Upper Saddle River.

[8] Ummah, S., \& Athambawa, S. (2018). Organizational citizenship behavior and job satisfaction among non-academic employees of national universities in the Eastern province of Sri Lanka.

[9] Paille, Pascal., Boiral, O,. Chen, Yang. (2013). Linking environmental management practices and organizational citizenship behaviour for the environment: a social exchange perspective. The International Journal of Human Resource Management, Vol. 24, No. 18, pp 3552-3575

[10] Zhao, H., \& Zhou, Q. (2019). Exploring the impact of responsible leadership on organizational citizenship behavior for the environment: A leadership identity perspective. Sustainability, 
11(4), 944

[11] Ghozali, Imam. (2016). Aplikasi Analisis Multivariate Dengan Program IBM SPSS 23 (Edisi 8). Semarang : Badan Penerbit Universitas Diponegoro

[12] Belias, Dimitrios, Koustelios, Athanasios. (2014). Transformational Leadership and Job Satisfaction in the Banking Sector: A Review. International Review of Management and Marketing, Vol. 4, No. 3, pp.187-200

[13] Abelha, Daniel Martins, et.al. (2018). Transformational Leadership and Job Satisfaction: Assessing the Influence of Organizational Contextual Factors and Individual Characteristics. Review of Business Management. v.20, p.516-532

[14] Mi, Lingyun, et.al (2019). A new perspective to promote organizational citizenship behafor the environment: The role of transformational leadership. Journal of Cleaner Production 239

[15] Sari, Eliana, et.al. (2019). How Could Management of School Environment Improve Organizational Citizenship Behaviors for The Environment? (Case Study at Schools for Specifics Purposes). Journal of Social Studies Education Research. 2019: 10 (2), 46-73

[16] Kalimullah, AM Nurhuda \& Nawangsari, Lenny Christina. Organization Citizenship Behavior for the Environment at Financial Institution. Volume 1, Issue 2, Desember 2019 , E-ISSN : 2686-6331, P-ISSN : 2686-6358

[17] Anis, Atif, et.al. (2011). Impact of organizational commitment on job satisfaction and employee retention in pharmaceutical industry. African Journal of Business Management Vol. 5(17), pp. 7316-7324

[18] Hartono, Brian dan Setiawan, Roy. (2013). Pengaruh komitmen organisasional terhadap kepuasan kerja karyawan Paparon's Pizza City of Tomorrow, AGORA Vol. 1, No. 1, 1-8 